\title{
Seafloor evidence for glaciation, northernmost Baffin Bay
}

\author{
WESTON BLAKE, JR., H. RUTH JACKSON \& CLAUDIA G. CURRIE
}

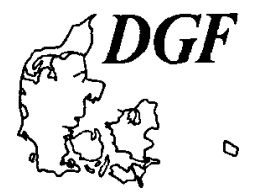

\begin{abstract}
Blake, W., Jr. Jackson, H. R. \& Currie, C. G.: Seafloor evidence for glaciation, northernmost Baffin Bay. Bulletin of the Geological Society of Denmark, Vol. 43, pp. 157-168. Copenhagen, 1996-12-05. https://doi.org/1-0.3757-0/bgsd-1996-43-15
\end{abstract}

\begin{abstract}
Shaped seafloor features were recorded at three localities on C.S.S. Hudson Cruise 91-039, to northernmost Baffin Bay. They resemble glacially sculptured bedrock hills, varying from 2.5 to $3.0 \mathrm{~km}$ in length, with relief of 70 to $>90 \mathrm{~m}$, and they occur in water depths of 200 to $400 \mathrm{~m}$. These well developed features occur to the west-southwest, east and north of Carey Øer, an isolated group of islands which bears strong evidence of having been overridden by glacial ice and on top of which marine shells in till are $>40000$ years old. The sculptured features at each of the three sites are asymmetric, with well developed stoss and lee sides. Their shapes and orientations are consistent with the hypothesis of a southward-flowing Smith Sound Ice Stream expanding into northernmost Baffin Bay. The Smith Sound Ice Stream is believed to have existed most recently at the Late Wisconsinan gla-cial maximum, but southward-flowing ice reaching as far as Carey Øer at this time appears to be at variance with evidence assembled in the Dundas area, Green-land, which suggests a limited advance of ice during the Wolstenholme Fjord Stade.
\end{abstract}

Key words: Seafloor, glacial features, radiocarbon dating, Baffin Bay, Carey Øer.

Weston Blake, Jr., Terrain Sciences Division, Geological Survey of Canada, 601 Booth St., Ottawa, Ontario K1A OE8, Canada; H. Ruth Jackson and Claudia G. Currie, GSC-Atlantic, Bedford Institute of Oceanography, P. O. Box 1006, Dartmouth, Nova Scotia B2Y 4A2, Canada. July 25, 1996.

The main task of C.S.S. Hudson Cruise 91-039, in August and September of 1991, was to carry out a deep seismic refraction program in northernmost Baffin Bay (Figs 1,2), in order to try to resolve the ongoing controversy concerning the origin of Nares Strait (e.g., Christie et al. 1981, Okulitch et al. 1990, Jackson et al. 1992a, Jackson \& Reid 1994). Magnetic and gravity measurements were also made throughout the voyage, and a limited amount of shallow seismic reflection work was included in the scientific program (Jackson et al. 1992b).

A second task comprised both echo sounding and sediment coring to improve our understanding of marine surficial geology and Quaternary history in northemmost Baffin Bay. New areas were traversed, and two sites identified on C.S.S. Hudson Cruise 74-026 (cf. Blake \& Lewis 1975, Ross \& Falconer 1975) were revisited and cored (Fig. 2). The seafloor information complements the land-based data obtained around northernmost Baffin Bay (north of $76^{\circ}$ ) over the previ- ous two decades by Blake (1975,1977a, 1992a, 1992b), Weidick (1976a, 1976b, 1977), Kelly (1980, 1985, Kelly \& Landvik 1990) and by Funder and colleagues (see Funder \& Houmark-Nielsen 1990, Funder \& Mejdahl 1994, Funder \& Hansen 1996), especially with regard to: 1) ice extent at the last glacial maximum, and 2) the sequence of events during deglaciation. The main purpose of the present paper is to report the discovery of features on the seafloor which appear to be glacially sculptured bedrock. Also, new AMS ${ }^{14} \mathrm{C}$-age determinations are presented which contribute to the chronology of events in northernmost Baffin Bay.

\section{Methods}

Ocean bottom seismometers (OBS's) were used in the deep seismic refraction program, and every point along the planned refraction lines was crossed three times: 


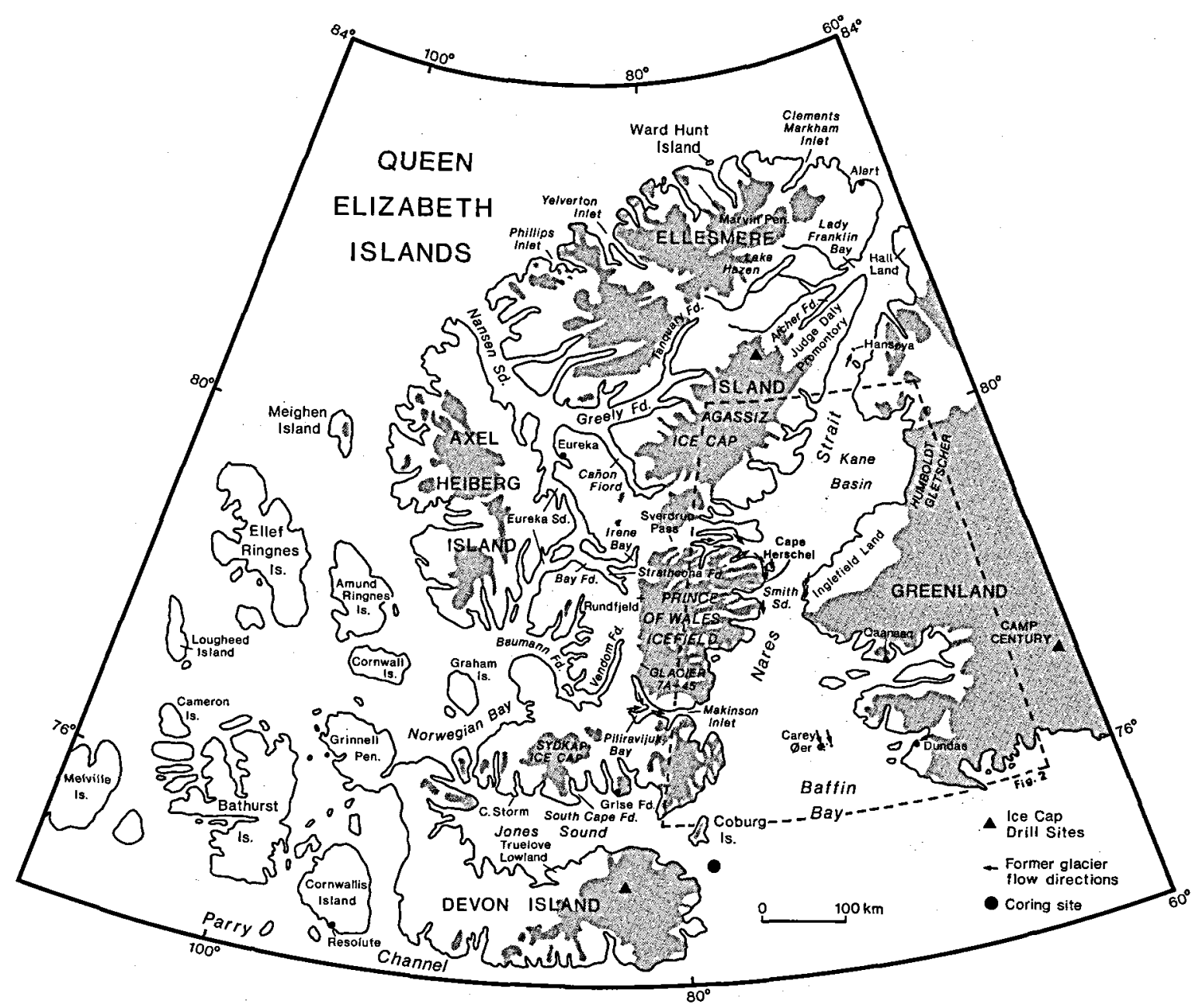

Fig. 1. Location map, Queen Elizabeth Islands and former ice flow directions along Nares Strait. The area covered by Figure 2, in which the seafloor glacial features occur, is outlined. The coring site SSE of Coburg Island is HU83-023-52, referred to in the text.

once when the OBS's were deployed at approximately $12 \mathrm{kts}$, a second crossing was made at slow speed ( $\sim \mathrm{kts}$ ) using airguns as an energy source, and a third traverse was again carried out at normal speed $(\sim 12$ $\mathrm{kts}$ ), with stops to recover the OBS's, which were programmed to lift off the seafloor at pre-arranged times. Because of the differences in ship speed during each pass, the apparent shape of the individual bedrock features varies. Therefore the crossings of the feature at Site 1 (Fig. 2) have been replotted at the same scale. Except for brief intervals when the ship was recovering the OBS's, the $3.5 \mathrm{kHz}$ echo sounder was operated continuously, yielding the records that form the basis for this paper.

The location of OBS line 1, along the edge of the North American continental shelf, was determined by H. R. Jackson from industry seismic reflection data compiled by K. Dickie (cf. Jackson et al. 1992a). This line was oriented NE-SW, from $76^{\circ} 53.5^{\prime} \mathrm{N}, 74^{\circ} 17.2^{\prime} \mathrm{W}$ to $75^{\circ} 11.5^{\prime} \mathrm{N}, 78^{\circ} 47.8^{\prime} \mathrm{W}$ (Fig. 2). OBS line 3 , oriented NNW-SSE, lay along the Greenland continental shelf, from $77^{\circ} 42.2^{\prime} \mathrm{N}, 74^{\circ} 10.0^{\prime} \mathrm{W}$ to $75^{\circ} 40.3^{\prime} \mathrm{N}, 70^{\circ} 35.0^{\prime} \mathrm{W}$. Navigation was by BIONAV, including a GPS receiver which allowed positioning to between 50 and $100 \mathrm{~m}$ (personal communication from A. E. Jackson, 1994). The orientation of these lines turned out to be particularly advantageous in terms of detecting evidence for former glacier flow, studied earlier by Blake (1977a) on Carey Øer.

\section{Previous observations on glacial geology}

The northernmost Baffin Bay region (north of $76^{\circ}$ ) has long held a fascination for those interested in glacial phenomena, as numerous scientists passed this way on 


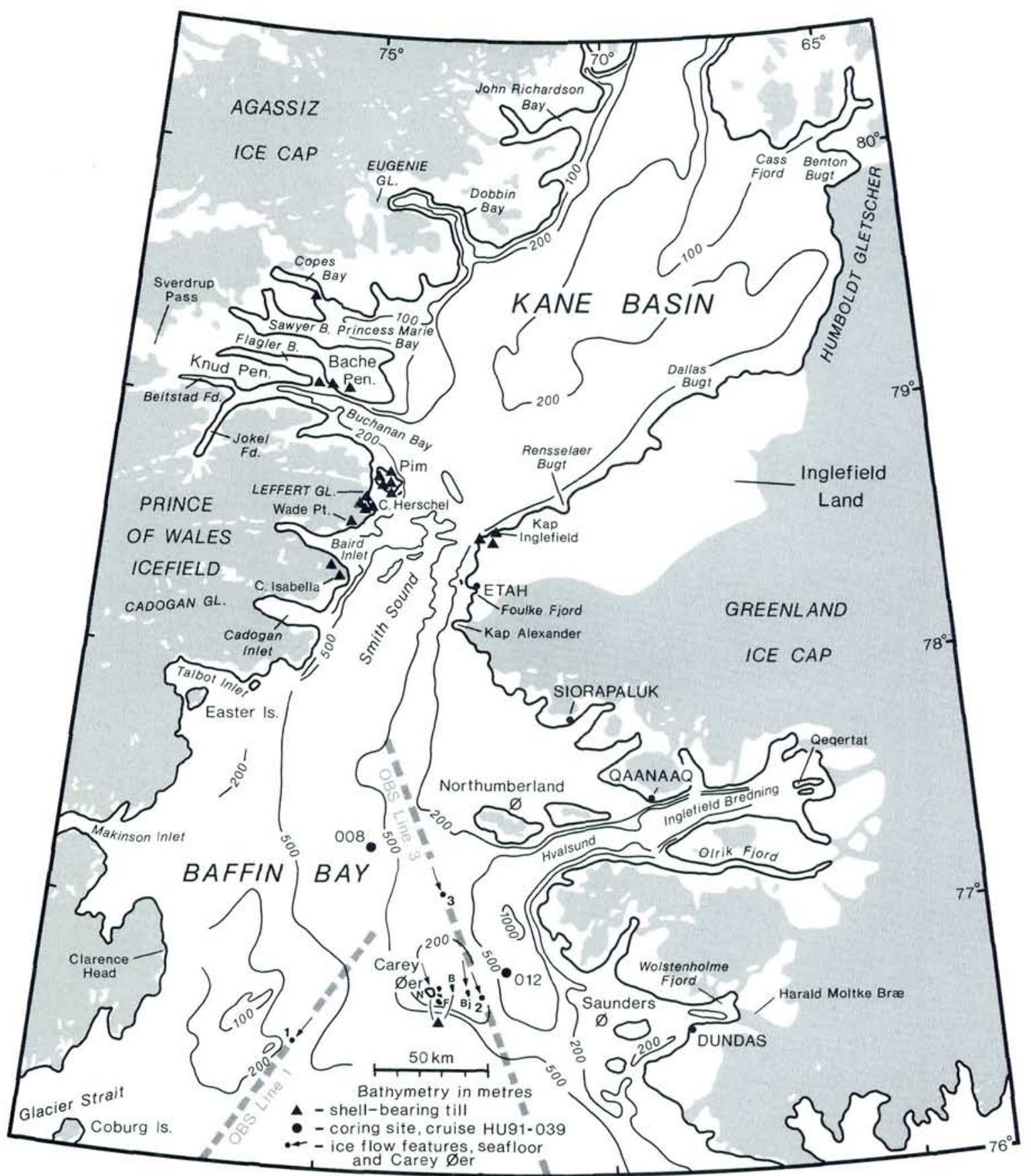

Fig. 2. Location map and ice-flow indicators, northernmost Baffin Bay (adapted from Monahan 1980). The main island in Carey $\emptyset$ er is Nordvestø $(\mathrm{N})$, and the other island on top of which shelly till was found is Bordø (B). Other islands are Björlings $\varnothing(\mathrm{Bj})$ and Fire $(\mathrm{F})$. Figures 1,2 and 3 refer to the seafloor features discussed in the text, along OBS lines 1 and 3. Coring sites HU91-039A-008P and $-012 \mathrm{P}$ are also indicated; ${ }^{14} \mathrm{C}$ age determinations from $012 \mathrm{P}$ are listed in Table 1. 


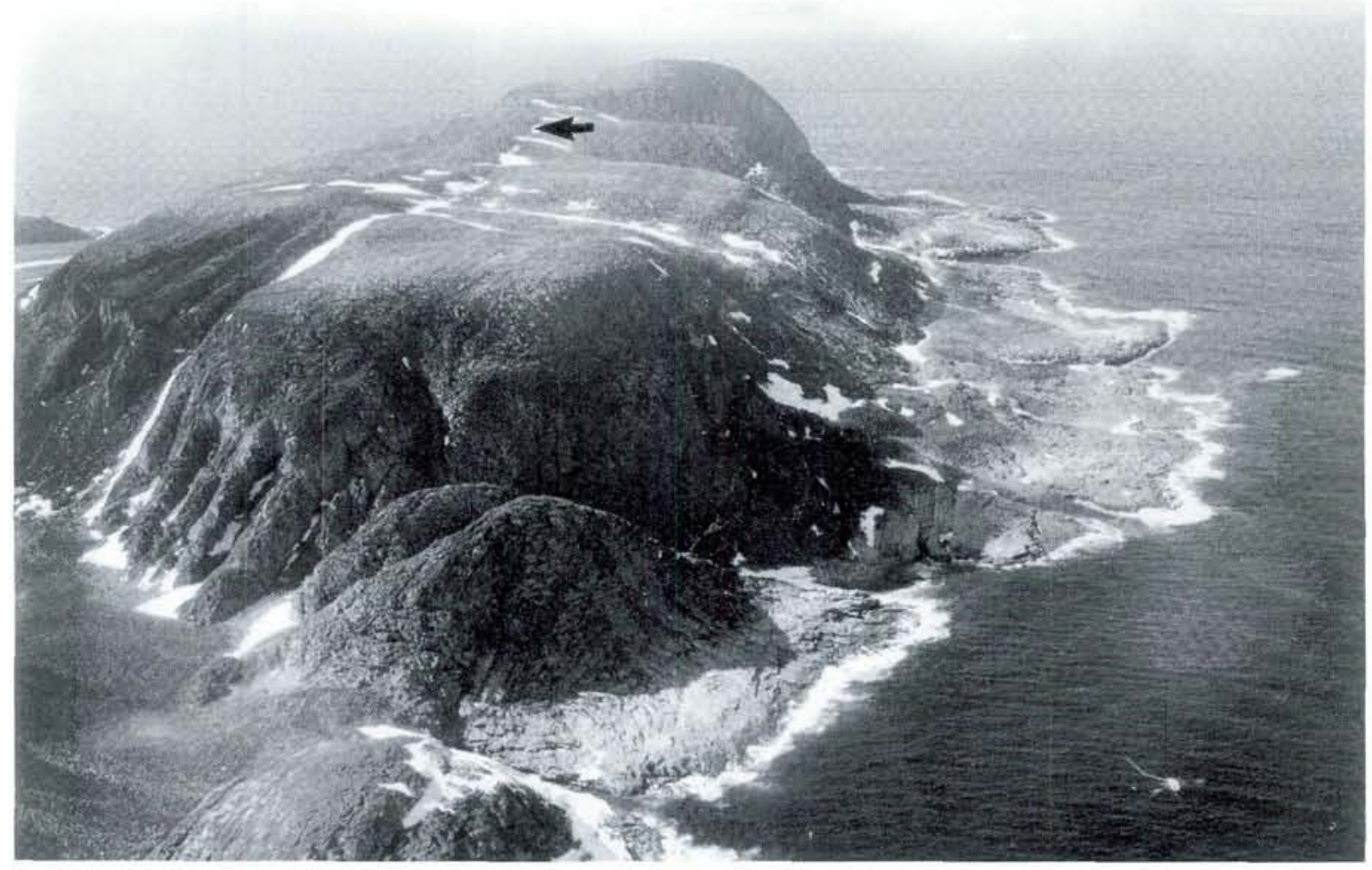

Fig. 3. Oblique aerial view northwestward along the north coast of Björlings $\emptyset$, Carey Øer. Note the rounded form of the main ESE-WNW ridge, approximately $1.6 \mathrm{~km}$ in length, which forms the backbone of the island. The direction in which ice flowed across the plateau is indicated by the arrow. W. Blake, Jr. July 23, 1976 (GSC-176789).

voyages of exploration in the late 19th and early 20th centuries. Although Nares (1878) noted the presence of red sandstone erratics on the gneissic summit plateau of the easternmost island (later named Björlings $\varnothing)$, the first to describe the glacial features on Carey Øer was T. C. Chamberlin, who visited the islands as a member of the Peary Auxiliary Expedition of 1894. Chamberlin $(1895 \mathrm{a}, \mathrm{b})$ observed the rounded shapes of Carey Øer and recorded the presence of glacial grooves on the summit of Björlings $\varnothing$. He also observed erratics of limestone, sandstone, shale and quartzite on the top of the island, at an elevation of $140 \mathrm{~m}$. The striae recorded glacial movement from the north and, taken together with the known presence of Paleozoic rocks in that region, led Chamberlin (1895a, b) to conclude that the glacier which overrode Carey Øer came from Smith Sound and beyond (Fig. 2). His ideas as to the extent of glaciation in northernmost Baffin Bay were summarized in the form of a map (Chamberlin 1913), but this map was rarely cited until Prest (1990) called attention to its existence. In a brief visit to Carey Øer in 1965, Bendix-Almgreen et al. (1967) did not record striae, polished rock surfaces, or fossiliferous surface till, but they did note that glacier ice had smoothed the plateau of Nordvest $\varnothing$, the largest island. They also commented on the widespread occurrence of erratics - limestone, sandstone, quartzite and conglomerate. These rock types are strikingly different from the orthogneiss, plus diabase, of which the islands are made up (Dawes 1991).

The first author of the present paper spent a month at the 'North Water Project' base on Nordvest $ø$ in 1976 (cf. Müller et al. 1973). Foot traverses were made over much of Nordvest $\varnothing$, and the summit plateaus of several other islands were visited by helicopter. Erratics were collected at each locality, and in some places the ground surface takes on a varicoloured aspect, so numerous are the pebbles, cobbles and boulders of quartzite, sandstone, dolomite, granite, etc. (Blake 1977a). Although a number of sedimentary lithologies are represented in the rocks of the Narssârssuk Group to the ESE near Dundas (Dawes 1991), the most logical source areas are to the north, for the rock types that occur as erratics on Carey Øer outcrop in Inglefield Land (Escher 1970, Dawes 1971). Furthermore, because of the sharp contacts between the diabase intrusives and the gneissic bedrock on the plateau of Nordvestø, the displacement of boulders of one type southward onto the other type of bedrock could be observed in a number of places. 


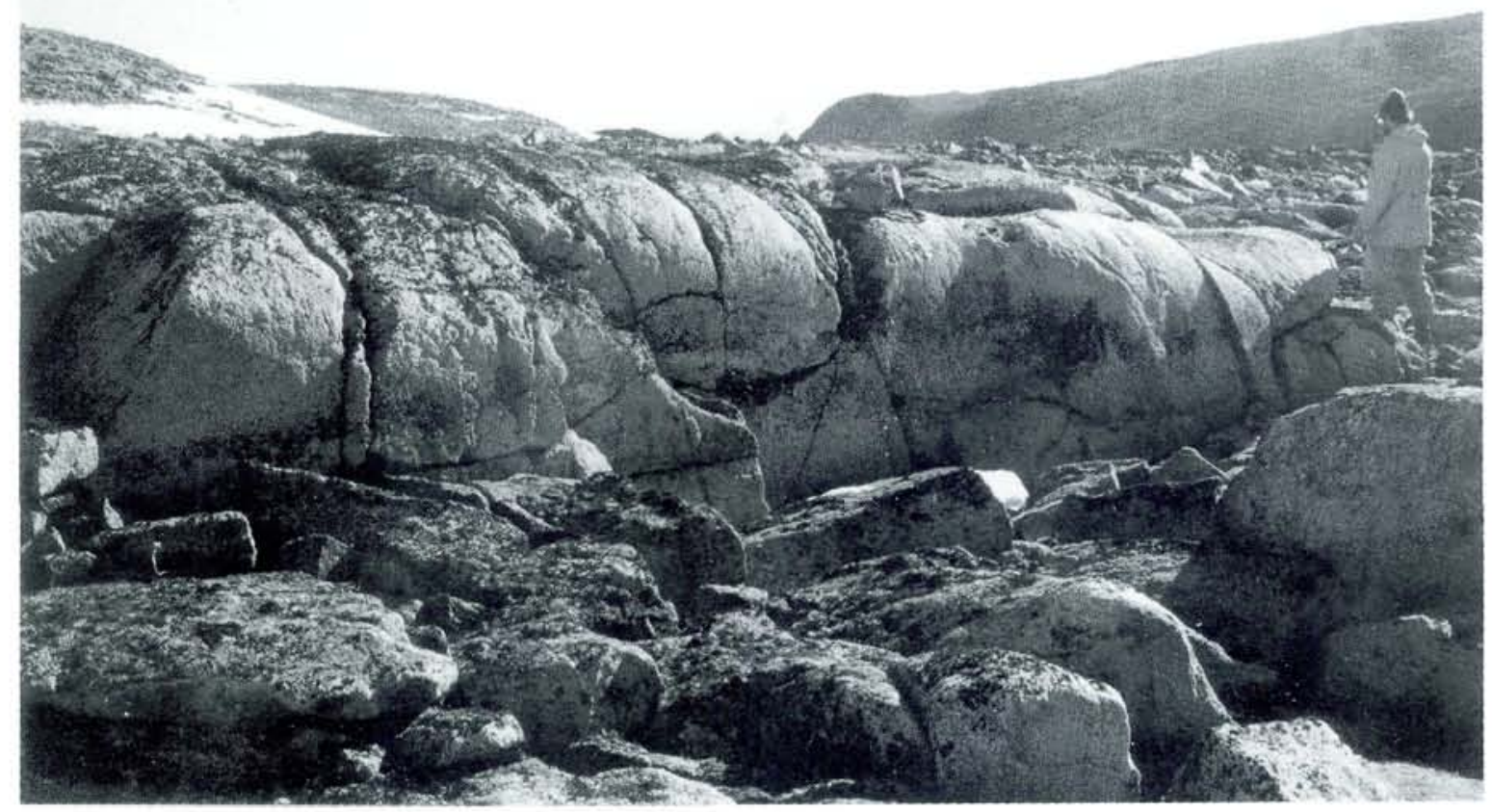

Fig. 4. View south-southwestward at a rounded outcrop of gneiss in a saddle on the plateau of central Nordvestø, Carey Øer. The former direction of ice flow was toward the deep valley whose west wall is visible on the skyline. W. Blake, Jr. August 11, 1976 (GSC-177578).

Striated outcrops were found on the summit plateaus of both Björlings $\varnothing$ (Fig. 3) and Fireø (the southernmost island), as well as at numerous sites on Nordvest $\varnothing$ (Fig. 4), even on the highest ridge at an elevation of $>220 \mathrm{~m}$. The outcrops were typically rounded on the north-facing stoss sides and plucked on the lee (south) sides. In addition, the gross morphology of the islands - i.e., cliffs tend to be better developed on the south sides (Fig. 3) - suggests overriding of the islands by glacier ice moving from north to south.

Offshore, the $500 \mathrm{~m}$-depth contour defines a trough leading southward from Smith Sound as well as one which originates in Inglefield Bredning; these troughs would have channeled ice streams towards Carey Øer (Fig. 2). In fact, the erosive action of ice streams may have played a major role in creating the troughs (cf. Pelletier 1966, Keen \& Barrett 1973), but glaciers are not mentioned by Monahan \& Johnson (1982) in their discussion of the physiography of Nares Strait. The sharp bend in the trough leading from Hvalsund and Inglefield Bredning may be structurally controlled, but it also may depict how the ice stream from the northeast was deflected southward by the more powerful Smith Sound Ice Stream coming from the north. Only $35 \mathrm{~km}$ northeast of Carey Øer, depths of over $1000 \mathrm{~m}$ are present in the trough leading southward from Hvalsund.
Fragments of marine shells, occurring as erratics in the till veneer and at elevations above $100 \mathrm{~m}$, were found on both Nordvest $\varnothing$ and Bord $\emptyset$ (Fig. 2). The shell sites were both located in saddles, just where the flow of ice across the islands would have been concentrated. This flow carried with it marine sediments dredged from the seabed to the north. Accelerator mass spectrometry (AMS) age determinations were made on two separate shell fragments from $120 \mathrm{~m}$ asl on Nordvestø; one was Hiatella arctica, the other was Astarte borealis, and both results were $>40000 \mathrm{BP}$ (Ua-4451 and -4452 , respectively; Table 1).

\section{Ice sculptured bedrock on the seafloor}

In view of the sculpture documented on Carey Øer it is not surprising that evidence for the southward flow of glacier ice is also present on the seafloor, especially as Site 2 is only $7.5 \mathrm{~km}$ ESE of Björlings $\varnothing$ (Fig. 2), i.e., closer to Björlings $\varnothing$ than that island is to Nordvestø.

The most striking landform among those traversed during the course of Cruise 91-039 was along OBS line 1, just over $60 \mathrm{~km}$ WSW of Nordvestø (Fig. 2). This feature, centred at approximately $76^{\circ} 35^{\prime} \mathrm{N}$, 
Table 1. New radiocarbon age determinations, Carey Øer and environs

\begin{tabular}{|c|c|c|c|c|}
\hline Sample no. ${ }^{l}$ & Species $^{2}$ & Lab.no. & $\begin{array}{l}\text { Apparent age }\left(T^{1 / 2}=5570\right) \\
\text { Normalized to } \\
\delta^{13} \mathrm{C}=-25 \% \text { o }\left(\mathrm{R}_{\mathrm{CONV}}\right)^{3}\end{array}$ & $\begin{array}{l}\text { Corrected to } \\
\delta^{13} \mathrm{C}=0 \% \text { o }\left(\mathrm{R}_{\text {CORR }}\right)^{3}\end{array}$ \\
\hline \multicolumn{5}{|c|}{ Core HU91-039A-012P (76 $48.3^{\prime} \mathrm{N}, 71^{\circ} 51.5^{\prime} \mathrm{W}$; water depth, $\left.823 \mathrm{~m}\right)$} \\
\hline 184-188 & benthic forams & $\mathrm{Ua}-3366$ & $10930 \pm 105$ & $10530 \pm 105$ \\
\hline $188-190$ & benthic forams & Ua-3367 & $10805 \pm 145$ & $10405 \pm 145$ \\
\hline 190-195 & benthic forams & $\mathrm{Ua}-4998$ & $10815 \pm 130$ & $10415 \pm 130$ \\
\hline \multicolumn{5}{|c|}{ Nordvestø, Carey $\varnothing \mathrm{er}\left(76^{\circ} 43.5^{\prime} \mathrm{N}, 73^{\circ} 11^{\prime} \mathrm{W} ; \sim 120 \mathrm{~m} \text { asl, shell fragments in till }\right)^{4}$} \\
\hline $76-119 \mathrm{~A}$ & Hiatella arctica & $\mathrm{Ua}-4451$ & $>40000$ & - \\
\hline $76-119 B$ & Astarte borealis & $\mathrm{Ua}-4452$ & $>40000$ & - \\
\hline
\end{tabular}

${ }^{1}$ For the core increments the sample number corresponds to the depth in $\mathrm{cm}$.

${ }^{2}$ Benthic foraminifera identified by Karen Luise Knudsen, Årus Universitet. Species of Cassidulina dominate in all three basal core samples. Pelecypods identified by W. Blake, Jr.

${ }^{3}$ Tandemlaboratoriet (Ua) at Uppsala Universitet normalizes to $-25 \%$ vs PDB, following the recommendation of Stuiver \&: Polach (1977). The first column gives the ages as reported by Tandemlaboratoriet. The second column shows the ages corrected to $0 \%$, so as to make them directly comparable to ${ }^{14} \mathrm{C}$ ages from the GSC and København (cf. Tauber 1979). Following Mörner \& Funder (1990), no additional correction has been made for the reservoir effect, believed to be negligible in the North-West Greenland area.

${ }^{4} \mathrm{For} \mathrm{Ua}-4451$ and -4452 , the inner $51 \%$ and $39 \%$, respectively, of shell material was used for the age determinations (personal communication from Göran Possnert, Oct. 1994).

$75^{\circ} 12^{\prime} \mathrm{W}$, is illustrated in Figs 5 and 6. It is interpreted as being a shaped bedrock hill - a gigantic whale-back $-3.0 \mathrm{~km}$ long and rising approximately $80 \mathrm{~m}$ above the general level of the seafloor. At the highest point recorded on the three traces the top of the hill is at a depth of $-353 \mathrm{~m}$. The northeast-facing side is clearly the rounded stoss side, whereas the southwest slope is the steeper and plucked lee side. Much of the bottom to the northeast is level at a depth close to $440 \mathrm{~m}$, and the seabed adjacent to the base of the rock hill, characterized by many point reflectors, is interpreted as being composed of unconsolidated material.

In Figure 6 all three passes across this feature have been combined by C. G. Currie using Autocad, so as to make allowance for the differences in ship's speed at each crossing. Because the ship's track diverged slightly on each occasion, the plots demonstrate the variability in the shape of the feature along essentially parallel lines, as close to one another as the ship could navigate.

The surficial marine sediments over most of northernmost Baffin Bay, including the area around Carey $\emptyset$ er, are classified as shelf deposits of glaciomarine origin; gravelly sandy mud of Latest Pleistocene Early Holocene age dominates, although the deep trenches bracketing Carey Øer contain Holocene glaciomarine clayey silt (Zarkhidse et al. 1991). The sculptured bedrock hill WSW of Nordvest $\varnothing$ occurs in an area characterized by the presence of basement at the seafloor (Jackson et al. 1992a). This interpretation of bedrock is based on data derived from industry airgun arrays, which were not tuned to detect unconsolidated sediments. A thin sediment cover may be present on this feature, but if so, the sediment thick-

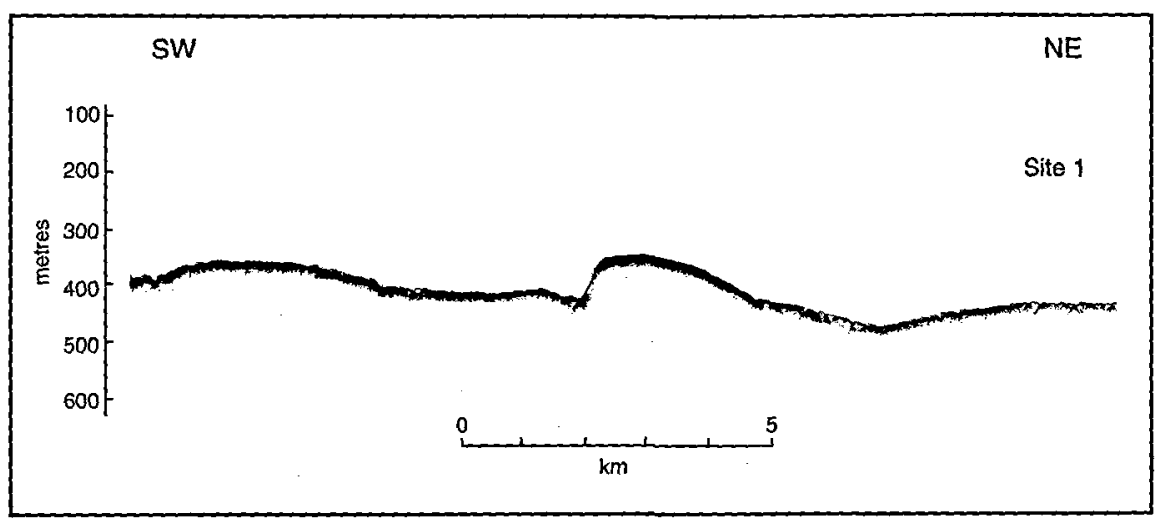

Fig. 5. Echo sounding trace $(3.5 \mathrm{kHz})$ of an $80 \mathrm{~m}-$ high shaped bedrock feature $\sim 60 \mathrm{~km}$ WSW of Nordvest $\varnothing$, Carey Øer (site 1 in Fig. 2). This trace was made with C. S. S. Hudson travelling southwestward at 3.5-3.6 kts (Day 235, 2155 to 2225 hours). 
Fig. 6. Autocad plots of three crossing of the same feature WSW of Nordvest $\varnothing$.

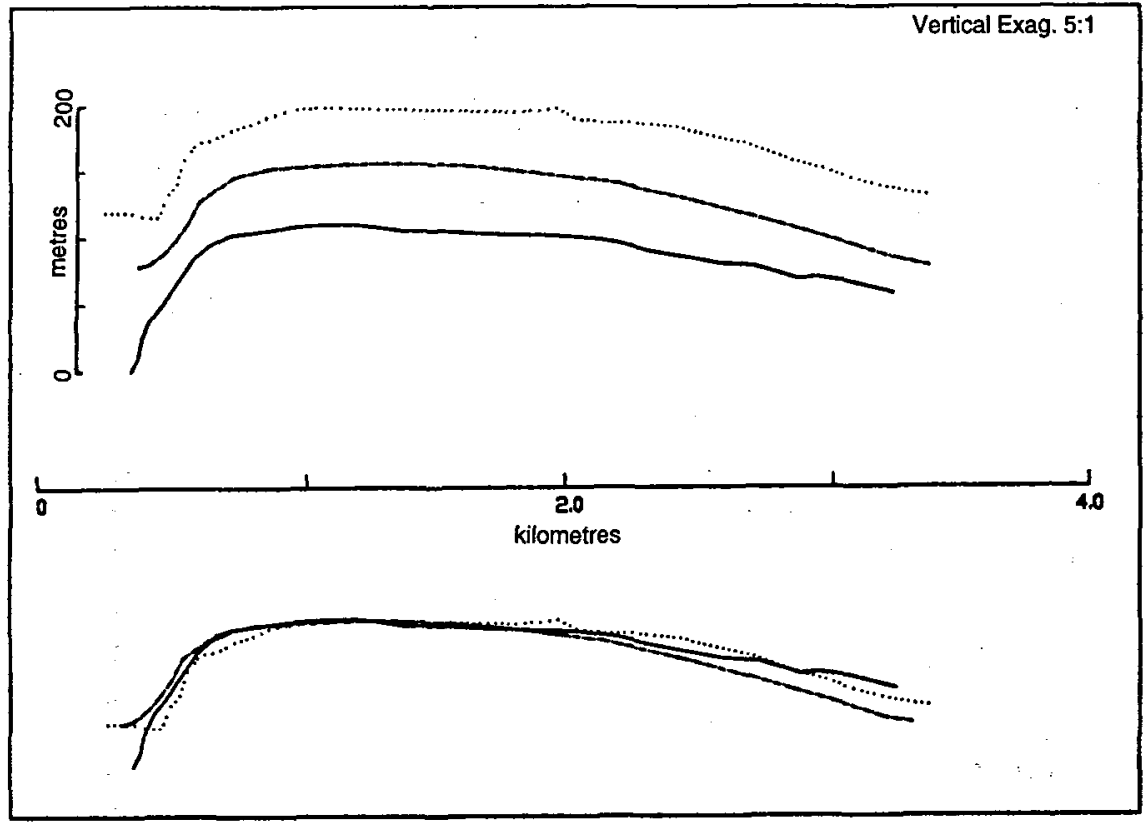

ness is less than the limit of acoustic resolution ( $\pm 1 \mathrm{~m}$ ). Thus there is no record of iceberg scour on the hill, although the surrounding sediments clearly have been scoured, and iceberg disturbance of the seabed at depths of $>400 \mathrm{~m}$ has been recorded at numerous sites in Baffin Bay (Lewis \& Woodworth-Lynas 1990).

The most prominent feature to the east of Carey Øer is shown in Figure 7 (Site 2). It is $2.5 \mathrm{~km}$ in length and, as noted earlier, this feature is only $7.5 \mathrm{~km}$ ESE of Björlings $\varnothing$, centred at approximately $76^{\circ} 42.6^{\prime} \mathrm{N}$, $72^{\circ} 14.8^{\prime} \mathrm{W}$. This hill rises $90 \mathrm{~m}$ above the adjacent seafloor (to the northwest) to a depth of $194 \mathrm{~m}$, and it is near the southeast corner of the plateau on which
Carey Øer are the high points (Fig. 2). The seafloor drops off to the SSE to depths exceeding $650 \mathrm{~m}$. To the northwest there is an extensive plain at $\sim 260 \mathrm{~m}$ depth. As with the sculptured hill to the WSW of Carey $\emptyset \mathrm{er}$, this feature is noticeably steeper on its south-facing (lee) side, and it exhibits a gentler stoss slope toward the NNW, in the direction from which the ice flowed.

Farther north, also along OBS line 3, another prominent sculptured bedrock hill was identified, at approximately $77^{\circ} 07.1^{\prime} \mathrm{N}, 72^{\circ} 59.5^{\prime} \mathrm{W}$ (Figs 2, 7). This site (3) is approximately $120 \mathrm{~km}$ south of the entrance to Smith Sound and $30 \mathrm{~km}$ southwest of Northumberland $\emptyset$,

Fig. 7. Echo sounding traces $(3.5 \mathrm{kHz})$ along OBS line 3. The upper trace shows a $90^{+} \mathrm{m}$-high bedrock feature $7.5 \mathrm{~km}$ ESE of Björlings $\varnothing$, Carey $\emptyset$ er (site 2 in Fig. 2). This trace was made with C.S.S. Hudson travelling northnorthwestward at 4.9-5.2 kts (Day 245, 1650 to 1720 hours). The lower trace shows a $70^{+} \mathrm{m}$-high bedrock feature $30 \mathrm{~km}$ southwest of Northumberland $\varnothing$ (site 3 in Fig. 2). This trace was made with C.S.S. Hudson travelling north-northwestward at 4.0-4.1 kts (Day 244, 1625 to 1750 hours).

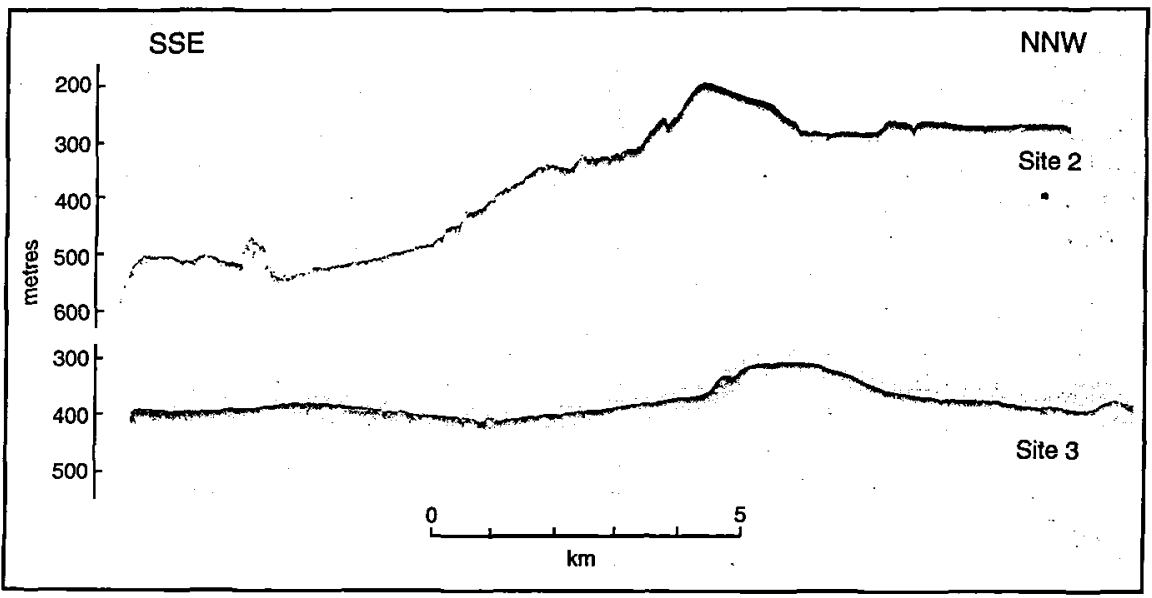


astride the shallower area between the two deep troughs where depths exceed $500 \mathrm{~m}$. Much of the relatively smooth seafloor to the NNW and SSE of this $3.0 \mathrm{~km}$ long feature lies between depths of 384 and $402 \mathrm{~m}$, and the highest point on the hill is at $316 \mathrm{~m}$ depth. Like the other stoss-and-lee hills described above, this asymmetric feature is more gently sloping toward the $\mathrm{NNW}$, in the direction from which the overriding glacier flowed.

\section{Discussion}

The earlier observations and collections from Carey Øer proved the passage of glacier ice across this isolated island group at some time in the past. The seafloor features documented here provide additional evidence that glacier ice once extended as much as $200 \mathrm{~km}$ southward from the confines of Smith Sound. The intense glacial scouring in the latter region, as well as in Makinson Inlet, Ellesmere Island (Fig. 1), has been documented in a series of papers (Blake 1977b, 1978, 1992a, 1992b, 1993, Blake et al. 1992).

Because the sea bottom features were crossed along a single, predetermined track (in actual fact three parallel tracks close to one another), we only know their shape in that orientation. It is worth noting, however, that on the western side of the central deep trough in northernmost Baffin Bay, the areas outlined by the $100 \mathrm{~m}$ contour are elongate in shape (cf. Pelletier 1966, Monahan 1980). That the configuration of these features is roughly parallel to the orientation of the ship's track along OBS line 1 is fortuitous, but it may also be that an enormous lobe of ice, flowing southward from Smith Sound, was expanding both toward the southwest and the southeast as it reached the wider part of Baffin Bay. On the east side of the central trough, numerous striae observations made on Carey Øer by Blake (unpublished data) are oriented approximately NNW-SSE, and all five of the major islands are elongated in NW-SE orientation. Furthermore, the seafloor features, $\sim 2.5$ to $>3.0 \mathrm{~km}$ in length, are comparable in size to the major islands in Carey Øer; these range from 1.5 to nearly $5.0 \mathrm{~km}$ in NW-SE orientation.

A search of the bathymetric records of earlier scientific cruises to northernmost Baffin Bay has revealed that few ship's tracks are oriented so that features like those discovered in 1991 would have been noticed. One possible exception is at a site some $50 \mathrm{~km}$ southwest of Saunders $\varnothing$, centred at $\sim 76^{\circ} 21.4^{\prime} \mathrm{N}, 70^{\circ} 36.8^{\prime} \mathrm{W}$, in $146 \mathrm{~m}$ of water. There an asymmetric feature was crossed by C. S. S. Hudson steaming southward on Cruise 78-029. This $2.5 \mathrm{~km}$-long 'high' ressembles those crossed on the 1991 cruise; it has a gentle stoss side to the north, a steep lee side to the south. Relief is $\sim 36 \mathrm{~m}$, and to the south the bottom drops off quickly to depths of over $600 \mathrm{~m}$.

If the glacial origin assigned to the features illus- trated in this paper is correct, then when were they sculptured? Two vastly different ideas have emerged with regard to the extent of ice during Late Wisconsin (Late Weichselian) time, both around northernmost Baffin Bay and farther north on Greenland, Ellesmere Island and Axel Heiberg Island (e.g., see Dawes 1987, England 1987, 1996, Hodgson 1989, Hughes 1987, Kelly \& Bennike 1992, Lemmen et al. 1994). Kelly \& Landvik (1990) and Funder \& Houmark-Nielsen (1990), as a result of their participation in the 1986 NORDQUA Field Excursion to Saunders $\varnothing$ and sites along and near Wolstenholme Fjord, placed the limit of Late Weichselian ice at the mouth of that fiord (Fig. 2). That is, they argued for a limited extent of Late Weichselian ice, the maximum position of the major outlet glacier (Harald Moltke Bræ) in the fiord being $\sim 20 \mathrm{~km}$ west of its present front during the Wolstenholme Fjord Stade. Funder (1989) had earlier suggested that Late Wisconsinan ice filled the whole of Nares Strait and northernmost Baffin Bay, including Carey Øer, and Weidick (1976a, p. 437) had indicated that Carey Øer were covered by coalesced ice sheets ("presumed extent of the Inland Ice during maximum glaciations"), without specifying a particular time. In the latest compilation, published in this journal, Funder \& Hansen (1996, Fig. 2) place the limit of ice at the last glacial maximum (LGM) to the west of Saunders $\varnothing$, i.e., farther west than the limit proposed in 1990 , but still not as far as Carey Øer. The LGM limit of the ice flowing out of Kane Basin is placed at the southern entrance to Smith Sound, and the limit at $10 \mathrm{ka}$ is juxtaposed to the south, still well over $100 \mathrm{~km}$ north of the seafloor feature at Site 3 and over $150 \mathrm{~km}$ north of Carey Øer (Funder and Hansen 1996).

On the basis of a study of striae and other ice-flow indicators, Blake (1977b, 1992a, b, 1993, and Blake et al. 1992) postulated that a major outlet glacier, the Smith Sound Ice Stream, flowed southward through Smith Sound into northernmost Baffin Bay in Late Wisconsinan time. This ice stream derived from the coalescence of the Greenland and Innuitian ice sheets over Kane Basin (Fig. 2). Evidence for this ice flow pattern is provided by the orientation and freshness of the striking glacier sculpture along both sides of Smith Sound as well as by the occurrence in the surface till at high elevations (i.e., above the Holocene marine limit) of marine shells, dredged from the sea bottom to the north. The concept of a Smith Sound Ice Stream is also in accord with Kravitz's (1982) analysis of the sediments in Kane Basin. Similar sculptured features have been created in Makinson Inlet by a major outlet glacier draining eastward into northernmost Baffin Bay.

The very significant emergence that has taken place in inner Makinson Inlet during Holocene time, as well as at Cape Herschel in Smith Sound, necessitates the former presence of a vastly thicker and more extensive ice load (e.g., see Tushingham 1991; Peltier 1994). This is despite the existence of major ice caps on both sides of northernmost Baffin Bay and Smith Sound 
today; i.e., ice depths of up to $800 \mathrm{~m}$ on the Prince of Wales Icefield (Koerner 1977), $225 \mathrm{~km}$ northwest of Carey Øer and $1390 \mathrm{~m}$ on the Greenland Ice Sheet at Camp Century (Fig. 1), $300 \mathrm{~km}$ east of Carey Øer (Dansgaard et al. 1969). The question remains, however, how far southward did the Smith Sound Ice Stream extend at the last glacial maximum?

Reeh (1984), in his reconstructions of the glacial ice covers of Greenland and the Canadian arctic islands, produced two maps covering the Nares Strait region. In the first reconstruction, where the ice margin (ice sheet/ice shelf transition line) is placed at the $200 \mathrm{~m}$ depth-contour, Carey Øer remain ice-free, at least in terms of major ice sheets. In the second reconstruction, where the ice margin is extended to $600 \mathrm{~m}$ depth, Carey Øer are overridden by coalescent ice from Greenland and Ellesmere Island, and the ice margin is depicted as lying to the south of the 76th parallel (cf. Fig. 2). Even had the ice not extended this far south, Carey Øer still may have been overridden.

With regard to deglacial chronology based on ${ }^{14} \mathrm{C}$ age determinations, the oldest Holocene sample collected by Blake in 1976 on Carey Øer was basal peat (99-104 cm depth) in a core on the Nordvest $\varnothing$ plateau (8940 90 years, GSC-2440; Brassard \& Blake 1978). The NORDQUA group's work on Saunders $\varnothing$ and along adjacent coasts in 1986 yielded several additional radiocarbon ages close to $9000 \mathrm{BP}$. The oldest Holocene result was $9150 \pm 95$ years $(\mathrm{K}-4781)$ on Hiatella arctica and Mya truncata shells (Mörner \& Funder 1990), although a value of $9880 \pm 500$ (M723) had been reported earlier for marine algae in a moraine at the head of Wolstenholme Fjord (Crane \& Griffin 1959). A slightly younger age of $8620 \pm 125$ (K-3504) was derived for a sample at $43 \mathrm{~m}$ asl composed of Hiatella arctica and Mya truncata from Qeqertat at the head of Inglefield Bredning (Fredskild 1985). Similar values have been reported from the opposite side of Baffin Bay (Fig. 2), the oldest results being on the same shell species in the 9000 to 10000 year-range near Clarence Head (Blake 1981, 1993). The only other ${ }^{14} \mathrm{C}$ ages from a marine sediment core in northernmost Baffin Bay are from HU83-023-052 $\left(75^{\circ} 35.2^{\prime} \mathrm{N}, 7^{\circ} 41.5^{\prime} \mathrm{W}\right.$; Fig. 1 ), in $512 \mathrm{~m}$ of water some $30 \mathrm{~km}$ southeast of Coburg Island (MacLean et al. 1984). The oldest Holocene date from this core, on shell material at $480-505 \mathrm{~cm}$ depth, is $8410 \pm 200 \mathrm{BP}$ (Beta-9712; Williams 1990).

Perhaps most interesting are three new ages on benthic foraminifera extracted by K. L. Knudsen from near the base of piston core $012 \mathrm{P}$, collected on Cruise HU91-039A. This core site (at 76 $48.3^{\prime} \mathrm{N}, 71^{\circ} 51.5^{\prime} \mathrm{W}$ ) is only $40 \mathrm{~km}$ northeast of Björlings $\emptyset$ (Fig. 2) but is within the eastern deep trough at a depth of $823 \mathrm{~m}$. Corrected results of $10530 \pm 105 \mathrm{BP}$ (Ua-3366; 184$188 \mathrm{~cm}), 10405 \pm 145 \mathrm{BP}(\mathrm{Ua}-3367 ; 188-190 \mathrm{~cm})$ and $10415 \pm 130 \mathrm{BP}(\mathrm{Ua}-4998 ; 190-195 \mathrm{~cm})$ have been obtained from this core (Table 1), which additional ${ }^{14} \mathrm{C}$ dating indicates is $\sim 7500$ years old at the top. The lowermost dated horizon is in a laminated clay unit just $10-15 \mathrm{~cm}$ above a diamicton (with striated clasts) at least $30 \mathrm{~cm}$ thick at the base of the core. This compact material caused refusal of the piston corer. The ${ }^{14} \mathrm{C}$ determinations are deemed accurate, as foraminifera and pelecypod fragments higher in Core $012 \mathrm{P}$ agree closely in age. These ages are older than the post-last glaciation marine shells from strata exposed above sea level on Saunders $\varnothing$, and they also predate the basal peat on Nordvest $\varnothing$, although moss growth may well have commenced prior to $9000 \mathrm{BP}$. One explanation for the time difference could be that a calving bay developed along the trough, which resulted in more rapid ice retreat there than on the adjacent islands. Furthermore, if Carey Øer and the other islands and coasts had not retained a cover of glacial ice, the effect of which was to exclude the sea, they should exhibit strata containing marine fossils which are as old as those in the trough, but they do not appear to do so.

\section{Conclusions}

Seafloor features that resemble glacially sculptured bedrock hills 2.5 to over $3.0 \mathrm{~km}$ in length were recorded at three sites in northernmost Baffin Bay on C.S.S. Hudson Cruise 91-039. Because the ship's track across each feature was at approximately the same azimuth on each of three occasions, their exact shape cannot be defined. However, all three features are markedly asymmetric, with well developed stoss and lee sides. The features are consistent with the hypothesis of a southward-flowing Smith Sound Ice Stream which expanded into the wider part of northernmost Baffin Bay and overrode Carey Øer. Although such an event presumably occurred on numerous occasions throughout the Pleistocene, stratigraphic evidence is not yet available to pinpoint the timing of the most recent inundation by ice from the north. In particular, a Late Wisconsinan glacial advance this far south is difficult to reconcile with the limited westward ice advance proposed by Funder \& Houmark-Nielsen (1990) and Kelly \& Landvik (1990) for the Wolstenholme Fjord stade less than $100 \mathrm{~km}$ to the east of the easternmost seafloor feature described here. On the other hand, the southward flowing ice stream in the deep trough on the east side of Carey Øer may have had a damming effect on the westward flow of ice out of Wolstenholme Fjord.

In the latest compilation (Funder \& Hansen 1996), the limit of southward-flowing ice at the last glacial maximum, as well as at $10000 \mathrm{BP}$, is placed at the southern entrance of Smith Sound. However, the fact that the oldest ${ }^{14} \mathrm{C}$ ages in Smith Sound are some 1500 years younger than those at the site of Core 012P suggests to us that the Smith Sound Ice Stream may well have extended farther south at the LGM. We need more signatures from the ocean bottom to resolve the ques- 
tion of glacial ice extent at the Late Wisconsinan glacial maximum, for at present we are operating with a limited data set. Better correlation between units exposed on land and marine sediment facies is also required in order to precisely define the various positions of changing ice margins through time.

\section{Acknowledgments}

The authors acknowledge the cooperation and assistance of the officers and crew aboard C.S.S. Hudson on Cruise 91-039. W. Blake, Jr. would like to thank Chief Scientist H. R. Jackson for choosing refraction lines with such interesting orientations for other studies, and C. G. Currie for numerous useful discussions with regard to the $3.5 \mathrm{kHz}$ records while on watchkeeping duties. Appreciation is expressed to K. L. Knudsen, Aarhus Universitet, Århus, for extracting the foraminifera for ${ }^{14} \mathrm{C}$-dating. Funds for AMS age determinations on Core HU-91-039A-012P were provided by grants to W. Blake, Jr. from Stiftelsen Ymer80, Stockholm, and the dating was carried by G. Possnert at Tandemlaboratoriet, Uppsala. Thanks are owed various GSC staff: S. Parnham (typing), T. Barry (drafting) and R. J. Kelly (photography). W. Blake, Jr. has benefitted by discussions with C. F. M. Lewis and B. MacLean, both of GSC Atlantic, Dartmouth, Nova Scotia. Comments which have helped to improve the manuscript have been provided by B. R. Pelletier and R. M. Koerner (both GSC Ottawa), H-P. Sejrup (Universitet i Bergen, Bergen), J. T. Andrews (University of Colorado, Boulder, Colorado), and for the journal, an anonymous reviewer and S. Funder (Geologisk Museum, Københavns Universitet, København). The last-named also kindly provided the translation for the Danish summary. Geological Survey of Canada Contribution 55193; Cape Herschel Project Contribution 58.

\section{Dansk sammendrag}

Morfologiske havbundsformer er observeret på tre lokaliteter på C.S.S. Hudsons togt 91-039 i den nordlige Baffin Bugt. De ligner glacialt udformede grundfjeldsbakker, varierende fra 2.5 til $3.0 \mathrm{~km}$ i længde, med relief på $70->90 \mathrm{~m}$ på vanddybder af 200-400 m. Disse veludviklede former er fundet vestsydvest, øst og nord for Carey Øer, en isoleret øgruppe med tydelige spor af gletschererosion. Tillaflejringer på toppen af фerne indeholder marine skaller, der er dateret til $>40,000$ år. Havbundsformerne er på alle tre lokaliteter asymmetrisk med veludviklede stød- og læsider. Deres form og orientering er i overensstemmelse med hypotesen om en isstrom i Smith Sund, der bevægede sig mod syd og bredte sig ud $\mathrm{i}$ den nordlige Baffin Bugt. Isstrømmen antages senest at have optrådt under Wisconsin (Weichsel) maksimum. Imidlertid strider det mod iagttagelser $i$ det nærliggende Dundas området i Grønland at isen skulle have strakt sig så langt sydpå som til Carey Øer på dette tidspunkt, idet der her tilsyneladende kun var tale om et mindre fremst $ø$ d, Wolstenholme Fjord stadiet (Funder \& Houmark-Nielsen 1990). Muligvis blokerede isstrømmen i det dybe trug på østsiden af Carey Øer gletscheren i Wolstenholme Fjord.

Eftersom de aldste 14C dateringer i Smith Sund er ca. 1500 år ældre end dem fra kerne 012P fra det dybe trug nordøst for Carey Øer er det sandsynligt at Smith Sund isstrømmen rakte længere mod syd end den sydlige ende af Smith Sund under sidste istids maksimum (cf. Funder \& Hansen 1996).

\section{References}

Bendix-Almgreen, S. E., Fristrup, B. \& Nichols, R. L. 1967: Notes on the geology and geomorphology of the Carey $\emptyset$, North West Greenland. Meddelelser om Grønland 164,19 pp.

Blake, W., Jr. 1975: Glacial geological investigations in northwestern Greenland. In Report of Activities, part A, Geological Survey of Canada, Paper 75-1A, 435-439.

Blake, W., Jr. 1977a: Radiocarbon age determinations from the Carey Islands, northwest Greenland. In Report of Activities, part A, Geological Survey of Canada, Paper 77$1 \mathrm{~A}, 445-454$.

Blake, W., Jr. 1977b: Glacial sculpture along the east-central coast of Ellesmere Island, Arctic Archipelago. In Report of Activities, part C, Geological Survey of Canada, Paper 77-1C, 107-115.

Blake, W., Jr. 1978: Aspects of glacial history, southeastern Ellesmere Island, District of Franklin. In Current Research, part A, Geological Survey of Canada, Paper 78-1 A, 175182.

Blake, W., Jr. 1981: Neoglacial fluctuations of glaciers, southeastern Ellesmere Island, Canadian Arctic Archipelago. Geografiska Annaler 63A, 201-218.

Blake, W., Jr. 1992a: Holocene emergence at Cape Herschel, east-central Ellesmere Island, Arctic Canada: implications for ice sheet configuration. Canadian Journal of Earth Sciences 29, 1958-1980.

Blake, W., Jr. 1992b: Shell-bearing till along Smith Sound, Ellesmere Island - Greenland: age and significance. In Robertsson, A-M., Ringberg, B., Miller, U. \& Brunnberg. L. (eds) Quaternary Stratigraphy, Glacial Morphology and Environmental Changes. Sveriges Geologiska Undersökning, Ca. 81, 51-58.

Blake, W., Jr. 1993: Holocene emergence along the Ellesmere Island coasts of northernmost Baffin Bay. Norsk Geologisk Tidsskrift 73, 147-160.

Blake, W., Jr. \& Lewis, C. F. M. 1975: Marine surficial geology: observations in the High Arctic, 1974. In Report of Activities, part A, Geological Survey of Canada, Paper 75-1A, 383-387.

Blake, W., Jr., Boucherle, M. M., Fredskild, B., Janssens, J. A. \& Smol, J. P. 1992: The geomorphological setting, glacial history and Holocene development of 'Kap Inglefield 
$S \varnothing^{\prime}$, Inglefield Land, North-West Greenland. Meddelelser om Grønland, Geoscience 27, 42 pp.

Brassard, B. R., \& Blake, W., Jr. 1978: An extensive deposit of the arctic moss Aplodon wormskoldii. Canadian Journal of Botany 56, 1852-1859.

Chamberlin, T. C. 1895a: Recent glacial studies in Greenland. Geological Society of America Bulletin 6, 199-220.

Chamberlin, T. C. 1895b: Geology. Appendix A in Bryant, H. G., The Peary Auxiliary Expedition of 1894. Bulletin of the Geographical Club of Philadelphia 1, 167-194.

Chamberlin, T. C. 1913: Map of North America during the Great Ice Age. Rand McNally, Chicago (scale: 1 inch to 104 miles $/ 169 \mathrm{~km}$ ).

Christie, R. L., Dawes, P. R., Frisch, T., Higgins, A. K., Hurst, J. M., Kerr, J. W., \& Peel, J. S. 1981: Geological evidence against major displacement in the Nares Strait. Nature 291, 478-480.

Crane, H. R. \& Griffin, J. B. 1959: University of Michigan radiocarbon dates IV. American Journal of Science, Radiocarbon Supplement 1, 173-198.

Dansgaard, W., Johnsen, S. J., Møller, J., \& Langway, C. C., Jr. 1969: One thousand centuries of climatic record from Camp Century on the Greenland Ice Sheet. Science 166, 377-381.

Dawes, P. R. 1971: The North Greenland fold belt and environs. Bulletin of the Geological Society of Denmark 20, 197-239.

Dawes, P. R. 1987: Topographical and geological maps of Hall Land, North Greenland. Grønlands Geologiske Unders $\emptyset$ gelse Bulletin 155, $88 \mathrm{pp}$.

Dawes, P. R. 1991: Geological map of Greenland (1:500000), Sheet 5, Thule. Grønlands Geologiske Undersøgelse.

England, J. 1987: Glaciation and the evolution of the Canadian high arctic landscape. Geology 15, 419-424.

England, J. 1996: Glacier dynamics and paleoclimatic change during the last glaciation of eastern Ellesmere Island, Canada. Canadian Journal of Earth Sciences 33, 779_ 799.

Escher, A. 1970: Tectonic/geologic map of Greenland. In Escher, A. (compiler with assistance from Henriksen, N., Dawes, P. R. \& Weidick, A). Geological Survey of Greenland (scale: 1:2 500 000).

Fredskild, B. 1985: The Holocene vegetational development of Tugtuligssuaq and Qeqertat, Northwest Greenland. Meddelelser om Grønland, Geoscience 14, $20 \mathrm{pp}$.

Funder, S. 1989: Quaternary geology of North Greenland. In Fulton, R.J. (ed.): Chapter 13 of Quaternary Geology of Canada and Greenland. Geological Survey of Canada, Geology of Canada. 1, 763-769.

Funder, S. \& Hansen, L. 1996: The Greenland ice sheet - a model for its culmination and decay after the last glacial maximum. Bulletin of the Geological Society of Denmark 42, 137-152.

Funder, S., \& Houmark-Nielsen, M. 1990: Local events and regional correlation. In Funder, S. (ed.): Late Quaternary stratigraphy and glaciology in the Thule area, Northwest Greenland. Meddelelser om Grønland, Geoscience 22, 4045.

Funder, S. \& Mejdahl, V. 1994: Luminescence dating tested on last interglacial shallow marine sediments in Greenland. In American Quaternary Association, Program \& Abstracts of the 13th biennial meeting (Minneapolis, Minnesota, June 1994), 211.

Hodgson, D. A. 1989: Quaternary stratigraphy and chronology (Queen Elizabeth Islands). In Fulton, R. J. (ed.)
Chapter 6 of Quaternary Geology of Canada and Greenland. Geological Survey of Canada, Geology of Canada no. 1 , pp. $452-459$.

Hughes, T. 1987: Ice dynamics and deglaciation models when ice sheets collapsed. In Ruddiman, W. F. \& Wright, H. E., Jr. (eds): North America and adjacent oceans during the last deglaciation. Boulder, Colorado, Geological Society of America, The Geology of North America, K3, 183-220.

Jackson, H. R. \& Reid, I. 1994: Crustal thickness variation between the Greenland and Ellesmere Island margins determined from seismic refraction. Canadian Journal of Earth Sciences 31, 1407-1418.

Jackson, H. R., Dickie, K. \& Marillier, F. 1992a: A seismic reflection study of northern Baffin Bay: implications for tectonic evolution. Canadian Joumal of Earth Sciences $29,2352-2369$.

Jackson, H. R., Loncarevic, B. D. \& Blake, W., Jr. 1992b: Shallow seismic and magnetic data from northernmost Baffin Bay: insights into geology. In Current Research, part B, Geological Survey of Canada, Paper 92-1B, 2329.

Keen, C. E. \& Barrett, D. L. 1973: Structural characteristics of some sedimentary basins in northern Baffin Bay. Canadian Journal of Earth Sciences 10, 1267-1278.

Kelly, M. 1980: Preliminary investigations of the Quaternary of Melville Bugt and Dundas; North-West Greenland. Grønlands Geologiske Undersøgelse, Rapport 100, 33-38.

Kelly, M. 1985: A review of the Quaternary geology of western Greenland. In Andrews, J. T. (ed.) Quaternary environments, eastern Canadian Arctic, Baffin Bay and western Greenland, Boston: Allen \& Unwin, 461-501.

Kelly, M. \& Bennike, O. 1992: Quaternary geology of western and central North Greenland. Grønlands Geologiske Undersøgelse Rapport 153, 34 pp.

Kelly, M. \& Landvik, J. Y. 1990: Summary of regional glaciation. In Funder, S. (ed.) Late Quaternary stratigraphy and glaciology in the Thule area, Northwest Greenland. Meddelelser om Grønland, Geoscience 22, 17-18.

Koerner, R. M. 1977: Ice thickness measurements and their implications with respect to past and present ice volumes in the Canadian High Arctic ice caps. Canadian Journal of Earth Sciences, 14, 2697-2705.

Kravitz, J. H. 1982: Sediments and sediment processes in Kane Basin, a High Arctic glacial marine basin. Institute of Arctic \& Alpine Research, University of Colorado, Occasional Paper No. 39, 184 pp.

Lemmen, D. S., Aiken, A. E. \& Gilbert, R. 1994: Early Holocene deglaciation of Expedition and Strand fiords, Canadian High Arctic. Canadian Journal of Earth Sciences 31, 943-958.

Lewis, C. F. M. \& Woodworth-Lynas, C. M. T. 1990: Ice scour. In Keen, M. J. \& Williams, G. L. (eds) Geology of the Continental Margin of Eastern Canada. Geological Survey of Canada, Geology of Canada, no. 2, 785-793.

MacLean, B., Woodside, J. M. \& Girouard, P. 1984: Geological and geophysical investigations in Jones Sound, District of Franklin. In Current Research, part A, Geological Survey of Canada, Paper 84-1A, 359-365.

Monahan, D. 1980: Baffin Bay bathymetry. Department of Fisheries and Oceans, Canadian Hydrographic Service, Chart 817-A (scale: 1:2000 000).

Monahan, D. \& Johnson, G. L. 1982: Physiography of Nares 
Strait: importance to the origin of the Wegener Fault. Meddelelser om Grønland, Geoscience 8, 53-64.

Mörner, N-A. \& Funder, S. 1990: C-14 dating of samples collected during the NORDQUA 86 expedition, and notes on the marine reservoir effect. Appendix in Funder, S. (ed.) Late Quaternary stratigraphy and glaciology in the Thule area, Northwest Greenland. Meddelelser om Grønland, Geoscience 22, 57-59.

Müller, F., Ohmura, A. \& Braithwaite, R. 1973: Das North Water Projekt. Geographica Helvetica 28, 111-117.

Nares, G. S. 1878: Narrative of a voyage to the Polar Sea, during 1875-6 in H. M. ships Alert and Discovery. London, Sampson Low, Marston, Searle \& Rivington, 3rd edition, $1,395 \mathrm{pp}$.

Okulitch, A. V., Dawes, P. R., Higgins, A. K., Soper, N. J. \& Christie, R. L. 1990: Towards a Nares Strait solution: structural studies on southeastern Ellesmere Island and northwestern Greenland. Marine Geology 93, 369-384.

Pelletier, B. R. 1966: Development of submarine physiography in the Canadian Arctic and its relation to crustal movements. In Garland, G. D. (ed.): Continental Drift. Royal Society of Canada, Special Publication 9, 77-101.

PeItier, W. R. 1994: Ice age paleotopography, Science 265, 195-201.

Prest, V. K. 1990: Laurentide ice-flow patterns: a historical review, and implications of the dispersal of Belcher Island erratics. Géographie physique et Quaternaire 44, 113136.

Reeh, N. 1984: Reconstruction of the glacial ice covers of Greenland and the Canadian Arctic Islands by three-dimensional, perfectly plastic ice-sheet modelling. Annals of Glaciology 5, 115-121.

Ross, D. I. \& Falconer, R. K. H. 1975: Geological studies of Baffin Bay, Davis Strait, and adjacent continental margins. In Report of Activities, part A, Geological Survey of Canada, Paper 75-1, 181-183.

Stuiver, M. \& Polach, H. A. 1977: Discussion of reporting of ${ }^{14} \mathrm{C}$ data. Radiocarbon $19,355-363$.

Tauber, H. 1979: ${ }^{14} \mathrm{C}$ activity of arctic marine mammals. In Berger, R. \& Suess, H. E. (eds) Radiocarbon dating. Proceedings of the Ninth International Conference, Los Angeles and La Jolla, 1976. Berkeley, University of California Press, 447-452.

Tushingham, A. M. 1991: On the extent and thickness of the Innuitian Ice Sheet: a postglacial-adjustment approach. Canadian Journal of Earth Sciences 28, 231-239.

Weidick, A. 1976a: Glaciation and the Quaternary of Greenland. In: Escher, A. \& Watt, W. S. (eds) The Geology of Greenland. Grønlands Geologiske Undersøgelse, 430458.

Weidick, A. 1976b: Glaciations of Northern Greenland new evidence. Polarforschung 46, 26-33.

Weidick, A. 1977: A reconnaissance of Quaternary deposits in northern Greenland. Grønlands Geologiske Undersøgelse, Rapport 85, 21-24.

Williams, K. M. 1990: Late Quaternary paleoceanography of the western Baffin Bay region: evidence from fossil diatoms. Canadian Journal of Earth Sciences 27, 14871494.

Zarkhidze, V. S., Fulton, R. J., Mudie, P. J., Piper, D. J. W., Musatov, E. E., Naryshkin, G. D. \& Yashin, D. S. 1991: Circumpolar map of Quaternary deposits of the Arctic. Geological Survey of Canada, Map 1818A (1:6000 000). 